\title{
Udział kompleksów SWI/SNF opartych na aktywności BRG1 w determinowaniu fenotypu komórek nowotworowych
}

\section{Maciej Sobczak,}

\section{Magdalena Strachowska,}

\section{Agnieszka Robaszkiewicz ${ }^{\varpi}$}

Katedra Biofizyki Ogólnej, Wydział Biologii i Ochrony Środowiska, Uniwersytet Łódzki

https://doi.org/10.18388/pb.2020_312

$\square_{\text {autor korespondujący: agnieszka.robaszkie- }}$ wicz@biol.uni.lodz.pl

Słowa kluczowe: związany z Brahma gen 1 (BRG1), regulowanie transkrypcji genów, epigenetyka, nowotwory

Wykaz stosowanych skrótów: BRK - domena BRM i KIS (ang. BRM and KIS), COMPASS kompleks białek związanych $\mathrm{z}$ metylotransferazą Set1 (ang. Complex Proteins Associated with Set1), CpG - regiony chromatyny bogate w cytozynę (C) i guaninę (G), DEXHc - domena helikazy zawierająca motyw DEXH (ang. DEXH-box Helicase), HELICc - domena charakterystyczna dla superrodziny helikaz (ang. Helicase Superfamily C-Terminal Domain), QLQ - domena zawierająca motyw Glutamina (Q) - Leucyna (L) - Glutamina (Q) , TCGA - baza danych zawierająca dane kliniczne pacjentów chorych na nowotwory (ang. The Cancer Genome Atlas)

\section{STRESZCZENIE}

A TP-zależne kompleksy remodelujące chromatynę stanowią ważny element epigenetycznego mechanizmu regulującego transkrypcję. Posiadają one zdolność do wstawiania, usuwania i przesuwania nukleosomów w obrębie elementów regulatorowych genów kontrolując w ten sposób dostępność DNA dla maszynerii transkrypcyjnej. Jednym z czterech zidentyfikowanych i opisanych dotychczas kompleksów jest SWI/SNF, w którym enzymatycznymi "motorami" są białka BRM i BRG1. Rosnąca liczba opublikowanych prac wskazuje na udział BRG1 w patofizjologii niektórych typów nowotworów, ponieważ aktywność tego enzymu odpowiada za ekspresję genów, których produkty kontrolują proliferację, naprawę DNA, transport przezbłonowy czy metabolizm. Inhibitory BRG1 i enzymów, które determinują aktywność BRG1 lub znakują histony mające ulec przemieszczeniu mogą stać się w przyszłości alternatywą dla obecnie stosowanych w terapiach związków hamujących wzrost guzów lub suplementem zwiększającym wrażliwość nowotworów na działanie leków przeciwnowotworowych.

\section{WPROWADZENIE}

Kompleksy remodelujące chromatynę odgrywają istotną rolę w determinowaniu fenotypu i funkcji komórek, ponieważ decydują o profilu ekspresji genów a w konsekwencji i o składzie proteomu. Obok enzymów wprowadzajacych i usuwających potranslacyjne modyfikacje histonów uczestniczą one w definiowaniu kodu epigenetycznego i intensywności transkrypcji, gdyż warunkują gęstość nukleosomów w obrębie regionów regulatorowych genów. Wykorzystując aktywność ATPazową głównej enzymatycznej podjednostki kompleksy te wstawiają, usuwają lub przesuwają nukleosomy tym samym zacieśniając lub rozluźniając chromatynę, której struktura decyduje o przyłączaniu kolejnych podjednostek maszynerii transkrypcyjnej do regionów regulatorowych genów. Dotychczas zidentyfikowano i opisano 4 główne, zależne od ATPaz rodziny kompleksów remodelujących chromatynę [1]: naśladujący SWI (ISWI; ang. Imitation Switch), helikaza wiążąca DNA o charakterze chromodomeny (CHD; ang. Chromodomain Helicase DNA-binding), INO80 oraz SWI/SNF (SWI, ang. Switch, SNF, ang. Sucrose Non-Fermenting). W skład wielopodjednostkowych kompleksów SWI/SNF wchodzą produkty rodziny genów SMARC, ale kluczową rolę dla zmian struktury chromatyny odgrywają dwa enzymy o wysokim stopniu homologii: Brahma - BRM (SMARCA2) i związany z Brahma gen 1 - BRG1 (SMARCA4; ang. Brahma-Related Gene 1). Skład białkowy kompleksów SWI/ SNF nie jest stały. Rdzeń kompleksu oprócz jednej lub obydwu ATPaz tworzą: białko typu SNF5 (SMARCB1) oraz dwa białka typu SWI3 (SMARCC1) występujące $\mathrm{w}$ formie dimeru. Różnorodność kompozycji pozostałych podjednostek umożliwia wysoce swoistą interakcję kompleksów z aktywatorami i represorami transkrypcji oraz rozpoznawanie poszczególnych modyfikacji histonów, co z kolei determinuje miejsce występowania kompleksów w obrębie genomu oraz kierunek lokalnej przebudowy chromatyny - jej zacieśnianie lub rozluźnianie. Kompleksom SWI/SNF przypisuje się rolę zarówno w wyciszaniu jak i aktywowaniu transkrypcji, jednak uniwersalny, decydujący o tym mechanizm pozostaje nieznany. Wynik ich działania uzależniony jest od rodzaju ATPazy, wzajemnych funkcjonalnych zależności pomiędzy nimi, składu podjednostek regulatorowych, rodzaju sekwencji promotorowej, typu komórek, ich aktualnego stanu: stopnia zróżnicowania, statusu proliferacji i aktywacji poszczególnych ścieżek sygnałowych.

Doniesienia literaturowe $\mathrm{z}$ ostatniej dekady jednoznacznie sugerują związek pomiędzy aktywnością BRG1 a transformacją i progresją przynajmniej niektórych typów nowotworów. Choć początkowo enzym ten uznawany był za supresora wzrostu guzów, wyniki najnowszych prac wykazały, że nasila on transkrypcję genów, których produkty odpowiedzialne są kilka ważnych cech fizjologicznych nowotworów decydujących o ich fenotypie i patofizjologii. 


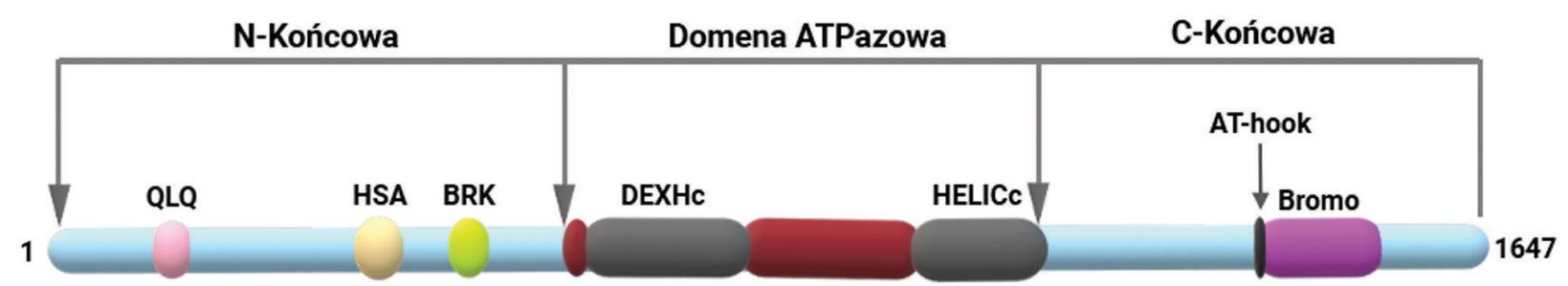

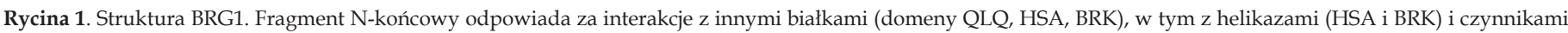

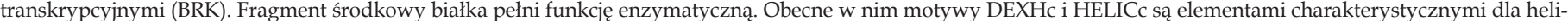

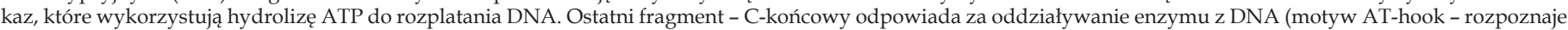
rowek mniejszy w helisie DNA) oraz z nukleosomami (Bromo - bromodomena - oddziałuje z acetylowanymi i metylowanymi nukleosomami).

\section{BRG1 - BUDOWA I FUNKCJE}

Ludzkie, jądrowe białko BRG1 (Ryc. 1) składa się z trzech regionów: N-końcowego pełniącego rolę regulatorową, regionu środkowego o aktywności ATPazy oraz regionu C-końcowego, odpowiadającego za oddziaływania z chromatyną i DNA [2]. W rejonie N-końcowym wyróżnić można domeny QLQ, HSA i BRK. Bogata w reszty proliny domena QLQ prawdopodobnie umożliwia fizyczny kontakt pomiędzy BRG1 i innymi białkami, podobnie jak domena HSA, która odpowiada za interakcję ATP-azy z innym członkiem kompleksu SWI/SNF - ARID1A. Doniesienia literaturowe sugerują, że domena BRK uczestniczy w oddziaływaniu $\mathrm{z}$ $\mathrm{m}$.in. helikazami chromodomenowymi oraz $\mathrm{w}$ regulowaniu transkrypcji [3]. Ponieważ BRG1 wykorzystuje hydrolizę ATP do zmiany konformacji chromatyny - przesunięcia DNA względem nukleosomów, $\mathrm{w}$ literaturze enzym ten występuje również pod nazwą ATPaza-translokaza [1,4]. W obrębie regionu środkowego tego enzymu można wyróżnić dwie domeny: DEXHc i HELICc. Pierwsza z nich zawiera region wiążący ATP i ATP-zależną domenę o aktywności helikazy zdolnej do rozluźniania DNA. Druga - domena HELICc, podobnie jak DEXHc, jest obecna w wielu białkach o aktywności helikazy i służy rozluźnianiu struktury kwasów nukleinowych [2]. Dla interakcji kompleksu SWI/ SNF z genomem najistotniejszy jest region znajdujący się na C-końcu, zawierający motyw wiążący DNA o strukturze haczyka (ang. AT-hook) i wykazujący wysoką swoistość względem regionów bogatych $\mathrm{w}$ adeninę oraz tyminę. Obecna w C-końcowym fragmencie bromodomena umożliwia oddziaływanie enzymu z acetylowanymi i metylowanymi (H3K4me3) resztami lizyny białek histonowych, ale również z DNA. Literatura wskazuje jednak, że domena ta nie odpowiada jedynie za wiązanie kompleksu SWI/SNF z chromatyną, lecz pełni także funkcję regulatorową [5-7]. Aktywność enzymatyczna białka BRG1 zmienia się w toku cyklu komórkowego. Wykazano, że białko Brahma u muszki owocowej, mające $74 \%$ podobieństwa do BRG1, ulega fosforylacji przez kompleksy Cyklina A/Cdk2 oraz Cyklina E/Cdk2. Identyczny mechanizm zaobserwowano w ludzkich komórkach, gdzie BRG1 fosforylowane jest przez Cyklinę E/Cdk2 [8]. Istnieją doniesienia o N-końcowej acetylacji ATPazy oraz jej oddziaływaniu z białkami SUMO (ang. Small Ubiquitin-like Modifier) [9], jednak rola acetylacji i sumoilacji w detereminowaniu aktywności enzymatycznej omawianego białka nie została dotychczas potwierdzona. $\mathrm{O}$ aktywności transkrypcyjnej BRG1 decydują pośrednio inne enzymy związane z chromatyną, które modyfikują histony znakując $\mathrm{w}$ ten sposób nukleosomy, mające ulec usunięciu $\mathrm{z}$ danego fragmentu chromatyny.

Przez wzgląd na pełnioną funkcję istotny jest mechanizm, który umiejscawia kompleks SWI/SNF w obrębie genomu i chromatyny. Według najnowszych doniesień literaturowych BRG1 występuje w przeważającej większości sekwencji promotorowych charakteryzujących się obecnością wysp CpG. W połowie tych regionów zidentyfikowano ponadto motyw dla wiązania czynników transkrypcyjnych z rodziny E2F, które łączą aktywność transkrypcyjną genu ze statusem proliferacji komórek. W ludzkich makrofagach oraz komórkach nowotworu piersi dla CpG/E2F-dodatnich promotorów funkcjonalnie powiązanych genów opisano nową jednostkę regulatorową, w skład której wchodzi kompleks SWI/SNF oparty na aktywności BRG1 oraz enzymy - acetylotransferaza EP300 i deacetylaza HDAC1 kontrolujące stopień acetylacji histonów [10,11]. Pierwszy z nich acetyluje reszty histonowe, które $\mathrm{w}$ formie zmienionej zostają rozpoznane przez BRG1. Prowadzi to do usunięcia nukleosomu, rozluźnienia chromatyny i $\mathrm{w}$ rezultacie do zainicjowania transkrypcji. HDAC1 usuwa reszty acetylowe z reszt lizyny uniemożliwiając usunięcie nukleosomów i tym samym faworyzuje zamkniętą - nieaktywną transkrypcyjnie chromatynę [10]. W części CpG/E2F-dodatnich promotorów kontrolowanych przez układ EP300-HDAC1-BRG1 obecne jest również białko PARP1 - powszechnie znane m.in. dzięki roli jaką odgrywa $w$ procesie naprawy uszkodzeń DNA. Przeprowadzana przez PARP1 ADP-rybozylacja EP300 warunkuje aktywność acetylazy przez co wpływa na stopień acetylacji histonów i w konsekwencji na transkrypcję genu. BRG1 również ulega ADP-rybozylacji, jednak brak tej modyfikacji nie wpływa na ekspresję genów, których aktywność jest niezależna od EP300 [12]. Kolejnym typem promotorów są te, w których BRG1 wchodzi w funkcjonalną i fizyczną interakcję z ASH2 i WDR6 - podjednostkami kompleksu białek związanych z metylotransferazą Set1 (COMPASS; ang. Complex Proteins Associated with Set1), który jest odpowiedzialny m.in. za wprowadzanie modyfikacji H3K4me3 [13,14]. Chociaż BRG1 jest powszechnie uważana za "czytnik" acetylowanych histonów, badania przeprowadzone dla genu GATA4 w kardiomiocytach linii H9c2 dowodzą, że enzym ten rozpoznaje także wspomnianą wyżej trójmetylację histonu H3, która podobnie jak acetylacja związana jest $\mathrm{z}$ aktywnymi transkrypcyjnie promotorami [7]. Komplex SWI/SNF można znaleźć również w obrębie genów, ponieważ jest elementem niezbędnym dla 
umożliwienia przemieszczania się kompleksu polimerazy 2 DNA $w$ trakcie elongacji [15].

Pomimo licznych doniesień literaturowych w dalszym ciągu nie udało się ustalić jednego mechanizmu, który definiowałby rozmieszczenie kompleksów SWI/SNF w genomie oraz kierunek ich działania w kontekście aktywowania i wyciszania ekspresji genów. W opisanych wyżej przykładach BRG1 wykazuje działanie pro-transkrypcyjne. W pewnych warunkach działanie tego enzymu jest jednak odwrotne, a zwiększenie jego ilości w promotorach związane jest z wyciszeniem genów. Jako przykład posłużyć mogą geny takie jak PARP1, CDK4 czy LIG1, których promotory również posiadają wyspę CpG oraz motyw dla E2F, a w odpowiedzi na zatrzymanie cyklu komórkowego w fazie G1 są miejscem tworzenia kompleksów represorów, w skład których wchodzą czynniki transkrypcyjne E2F1, białko RB1, deacetylaza HDAC1, kompleks polikomb 2 (PCR2; ang. Polycomb Repressive Complex 2) z metylotransferazą EZH2 i dodatkowe podjednostki kompleksu SWI/SNF, w tym także BRG1 $[11,16]$. Wydaje się, że przynajmniej w przypadku omawianych genów kontrolowanych przez promotory CpG/E2F-zależne aktywność transkrypcyjna BRG1 determinowana jest przez status proliferacji komórek i stopień fosforylacji białek z rodziny retinoblastoma. Stąd w szybko dzielących się komórkach BRG1 może przyczyniać się do nasilenia transkrypcji genów istotnych dla patofizjologii nowotworów, a w komórkach prawidłowych/zróżnicowanych/niedzielących się wyciszać je.

\section{MUTACJE I ZMIANY POZIOMU BRG1 W TRANSFORMACJI NOWOTWOROWEJ}

Z uwagi na opisane wyżej funkcje BRG1 jako regulatora transkrypcji, enzym ten jest stosunkowo dokładnie przebadany pod kątem potencjalnego związku jego mutacji z rozwojem nowotworów. Mutacje punktowe, insercje i delecje w obrębie genów kodujących BRG1 oraz kluczowe podjednostki kompleksu SWI/SNF - ARID1A czy SNF5 występują średnio w 20\% nowotworów ludzkich. Zidentyfikowano je w nowotworach: płuc, jajników, układu pokarmowego, prostaty, a także w chłoniakach, glejakach oraz czerniakach [17]. Mogą one powodować nabywanie lub utratę funkcji białek, wpływać na poziom ich ekspresji czy aktywność enzymatyczną ATPaz [15].

Mutacje wywołujące inaktywację BRG1 obecne są w 25\% linii niedrobnokomórkowego raka płuc (NSCLC), a gen kodujący BRG1 zajmuje czwarte miejsce wśród genów najczęściej ulegających mutacjom $\mathrm{w}$ tym typie nowotworu [18]. Brak ekspresji BRG1/BRM u pacjentów z NSCLC skutkuje krótszym przeżyciem w porównaniu do guzów, w których ekspresja BRG1/BRM jest zachowana [19]. W wielu typach nowotworów zaobserwowano, że mutacje skutkujące utratą ekspresji BRG1 oraz BRM mogą znacząco wpływać na proliferację komórek poprzez inaktywację ścieżki sygnałowej związanej z białkami retinoblastoma - RB: RB1, RBL1 oraz RBL2, będącymi kluczowymi czynnikami kontrolującymi przebieg cyklu komórkowego. Co istotne przywrócenie ekspresji BRG1 jak i BRM skutkowało zatrzymaniem wzrostu komórek przez białka z rodziny RB [20]. Mutacje zwiększające aktywność czy prowadzące do nadekspresji BRG1 mogą również sprzyjać wzrostowi guzów, ponieważ enzym ten kontroluje transkrypcję genów odpowiedzialnych za proliferację i naprawę uszkodzeń DNA [11]. Analiza danych zdeponowanych $\mathrm{w}$ bazie amerykańskiego instytutu do badań nad nowotworami (TCGA; ang. The Cancer Genome Atlas) wykazała, że mutacje ATPazy w inwazyjnych rakach piersi dotyczyły tylko mniej niż $2 \%$ wszystkich badanych przypadków, ale nadekspresję enzymu stwierdzono już w nowotworach pierwotnych i dotyczyły one od 35\% do aż 100\% przypadków w zależności od badanego typu nowotworu. Wyższy poziom BRG1 zidentyfikowano w raku jajnika, piersi, płuc i bardzo często wiązał się on z gorszym rokowaniem dla chorego [21]. Fakt, że nadekspresja BRG1 prowadzi do pogorszenia prognozy potwierdzają badania przeprowadzone na pacjentach $\mathrm{z}$ przewodowym rakiem piersi, u których zaobserwowano mniejszą przeżywalność i krótszy czas wolny od nawrotów. Dodatkowo, nadekspresja BRG1 predysponowała do przerzutowania [22].

Również druga z ATPaz kompleksu SWI/SNF - BRM ulega mutacjom chodź w odróżnieniu od BRG1 pojawiają się one znacznie rzadziej. Zmiana polega przeważnie na obniżeniu poziomu BRM. Występuje ona zwykle w nowotworach łagodnych i charakteryzujących się dobrym rokowaniem $[21,23]$.

Kolejną podjednostką SWI/SNF, której aberracje predysponują do rozwoju nowotworów, jest ARID1A. Podobnie jak w przypadku BRG1, mutacje tego genu obserwowane są w wielu typach nowotworów, ale najczęściej (bo aż w 50\% przypadków) dotyczą jasnokomórkowego raka jajnika, a utrata ARID1A może być jednym z pierwszych etapów jego rozwoju [23,24]. Wykazano także, że spadek poziomu ARID1A pogarsza rokowanie pacjentów z nowotworami piersi [25].

Mutacje w obrębie SNF5 są obecne w 95\% guzów rabdoidalnych - typowych dla wieku dziecięcego, które pojawiają się najczęściej w obrębie nerek i ośrodkowego układu nerwowego. W tych nowotworach mutacje genu kodujaccego SNF5 powodują najczęściej jego zanik w komórce [23]. Mutacje genu PBRM1 obniżają lub całkowicie wyciszają jego ekspresję. Najczęściej spotykane są w jasnokomórkowym raku nerek, gdzie predysponują komórki do proliferacji i przerzutowania, a także wpływają na poziom cytokin: zwiększając produkcję Il-6ST i hamując wydzielanie Il-8, Il-6 i CXCL2 [26]. W niektórych guzach PBRM ulega nadekspresji i nasila transkrypcje genów takich jak EpCAM, TGF- $\beta$, CDH2 warunkujących agresywność nowotworu [27].

ARID2, ulega mutacjom inaktywującym w nowotworach wątroby (spowodowanych przez HPV) oraz w czerniakach [28]. W pierwszym typie utrata ARID2 powoduje zmniejszoną ekspresję interferonów kontrolowanych przez ARID2, co może prowadzić do niekontrolowanej proliferacji zarażonych wirusem komórek wątroby predysponując z kolei do rozwoju nowotworu [29].

Opisane mutacje w genach SNF5, ARID1A, PBRM oraz $B R M$ mogą okazać się istotne dla biologicznej roli BRG1, ponieważ białka z nich powstające występują w bezpośrednim sąsiedztwie opisywanej ATPazy jako elementy komplek- 
sów SWI/SNF i regulują ich aktywność transkrypcyjną. W szczególności istotne dla funkcjonowania SWI/SNF wydają się być mutacje SNF5, białka które stanowi obok ATPaz rdzeń kompleksu. W odniesieniu do interakcji z BRM, ale także obecności ważnych jednostek regulatorowych m.in. ARID1A/B i PBRM kompleksy SWI/SNF podzielić można na 2 grupy: BAF i PBAF. W pierwszej z nich BRG1 działa samodzielnie, w drugiej towarzyszy mu BRM i kontekście transkrypcji ATPazy te zarówno współdziałają jak i wykazują działanie antagonistyczne [30]. Molekularne podstawy ich wzajemnego oddziaływanie nie zostały dotychczas wyjaśnione. Towarzyszą im białka ARID1A lub ARID1B pełniące w komórkach nowotworowych rolę supresora transkrypcji zależnej od BRG1/BRM [31]. Dla przykładu, pozbawienie komórek jasnokomórkowego raka jajnika aktywności ARID1A uwalniało spauzowaną w obrębie proksymalnych promotorów polimerazę 2 RNA indukując masywną ekspresję genów. Działanie kompleksów PBAF opiera się wyłącznie na aktywności BRG1, któremu zawsze towarzyszy białko PBRM uznawane za supresora transkrypcji i ARID2 łączący aktywność SWI/SNF z receptorami jądrowymi.

\section{ROLA BRG1 W REGULOWANIU TRANSKRYPCJI W KOMÓRKACH NOWOTWOROWYCH}

Białko BRG1 uczestniczy w regulowaniu transkrypcji genów kluczowych dla przetrwania i wzrostu nowotworu (Ryc. 2). Zjawiska aberracji w systemach kontroli cyklu komórkowego, skutkujące omijaniem punktów kontrolnych i prowadzące do niekontrolowanych podziałów, leżą u podstaw kancerogenezy. Kluczowymi dla regulacji przebiegu cyklu komórkowego są wspomniane wcześniej białka z rodziny retinoblastoma, które oddziałują z BRG1 i mogą odpowiadać za zatrzymanie cyklu komórkowego w komórkach, nowotworu jelita grubego [32]. Ostatnio opublikowana praca opisuje udział BRG1 w pozytywnej regulacji progresji nowotworu piersi, gdzie enzym ten stymuluje ekspresję genów, których produkty odpowiedzialne są za proliferację komórek. Wśród nich wymienić można między innymi kinazy zależne od cyklin i cykliny umożliwiające przechodzenie komórek przez kolejne fazy cyklu (CDK2, CDK4, CCNB), białka punktów kontrolnych reagujące na zaburzenia integralności genomu (CHEK2) oraz białka uczestniczące w replikacji DNA, tworzące rusztowanie dla
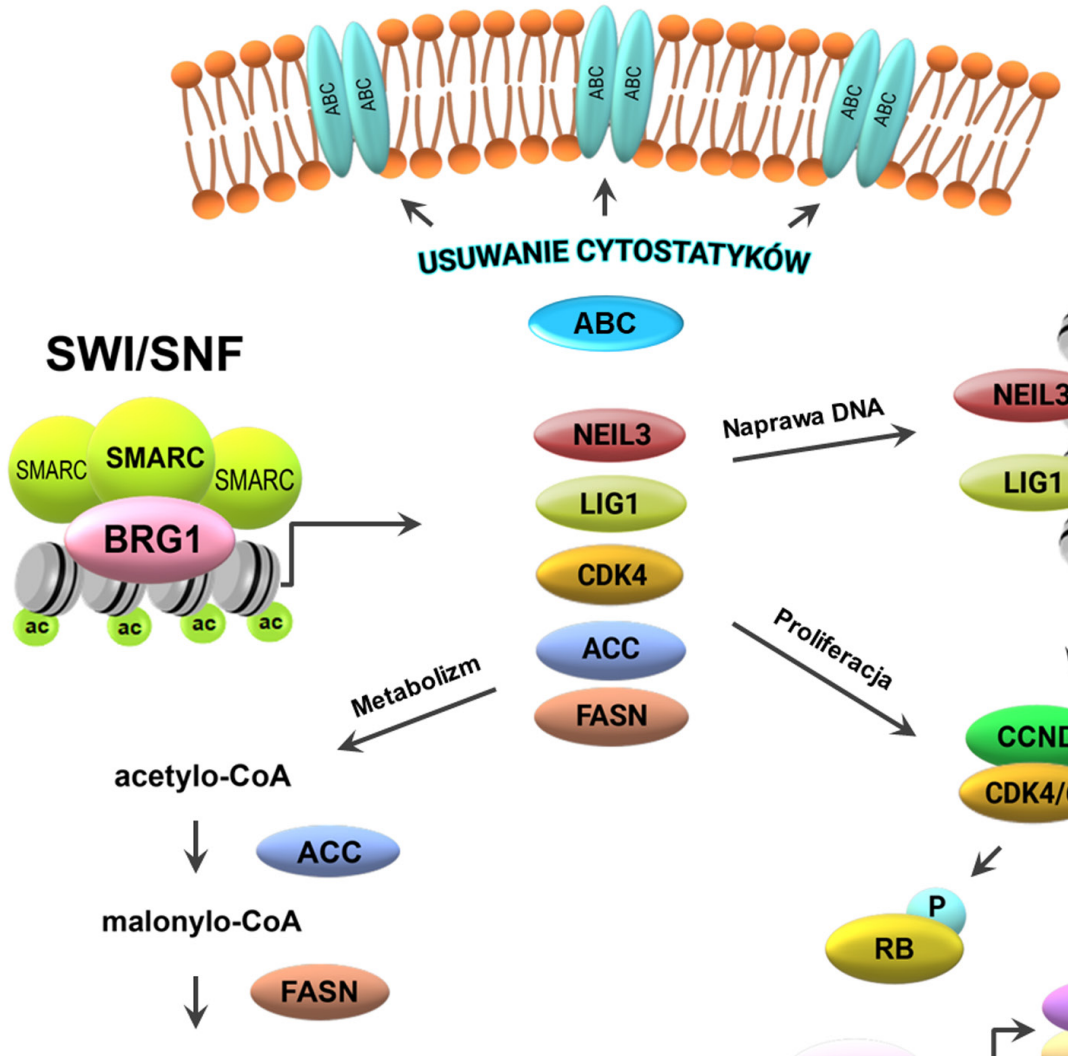

kwas palmitynowy
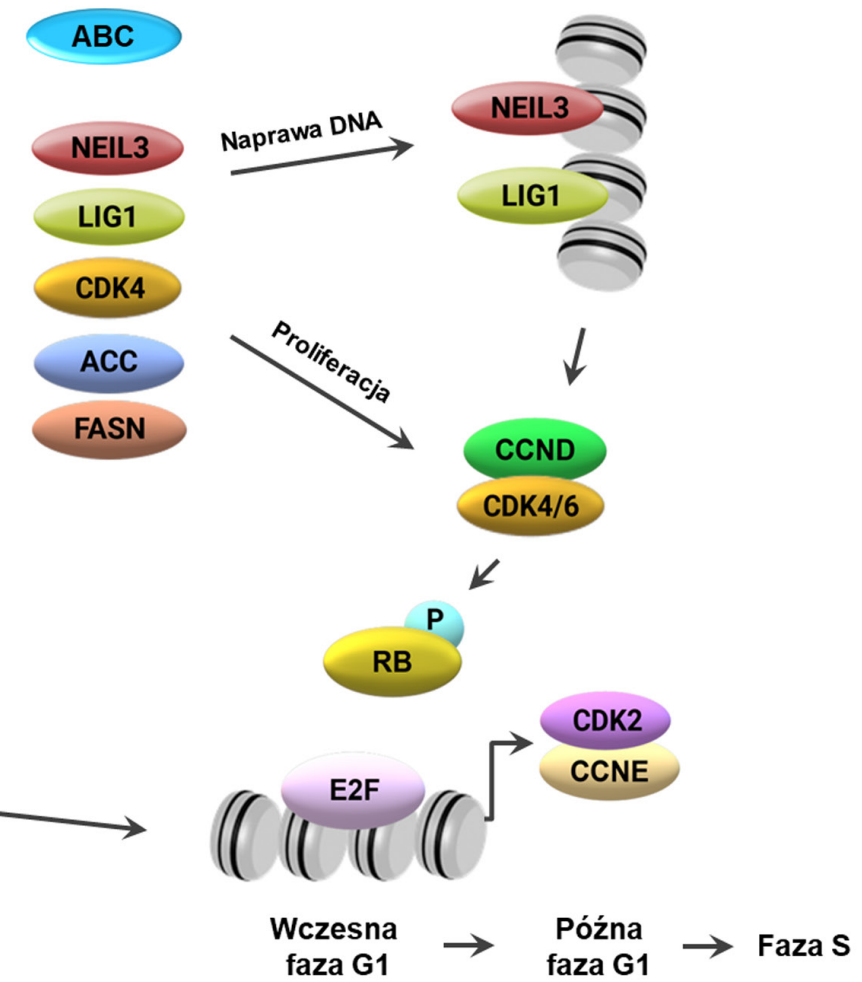

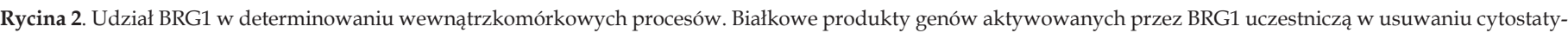

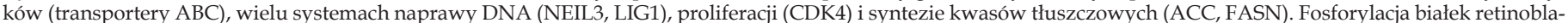

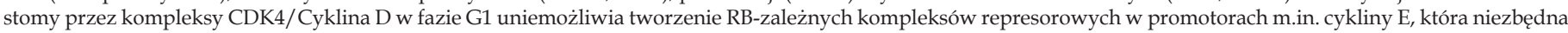

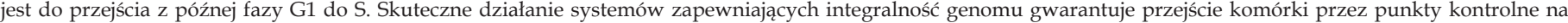

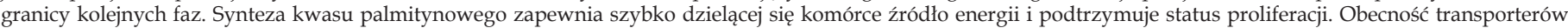
$\mathrm{ABC}$ w błonie chroni komórkę przed niekorzystnym działaniem toksycznych związków. 
polimerazy DNA (PCNA). Na opublikowanej liście genów związanych z proliferacją, które ulegają nadekspresji w komórkach nowotworu piersi i charakteryzują się obecnością BRG1 w ich acetyloywanych promotorach znajdują się również białka tworzące kinetochor, polimerazy DNA i czynniki replikacji takie jak GINS1-4 i RFC3-4. W opisanym modelu BRG1 działa dwojako: (a) bezpośrednio reguluje ekspresję genów związanych z proliferacją usuwając z ich sekwencji promotorowych acetylowane nukleosomy; (b) stymulując podziały mitotyczne zapobiega tworzeniu się represyjnych kompleksów RB1-HDAC1-EZH2 w obrębie motywów E2F na ich promotorach, uniemożliwiając tym samym zatrzymanie cyklu komórkowego w fazie G1 [11]

Geny, których produkty są elementem systemów naprawy DNA ulegają często mutacjom w nowotworach. Abberacje powodujące zaburzenia w mechanizmach odpowiedzialnych za usuwanie uszkodzeń materiału genetycznego $\mathrm{w}$ połączeniu z utratą kontroli na granicy kolejnych faz cyklu komórkowego są ściśle związane ze złośliwą transformacją. Chociaż niestabilność genomu jest konieczna dla zmiany komórek prawidłowych $\mathrm{w}$ nowotworowe to od pewnego momentu również komórki nowotworowe mogą potrzebować skutecznych systemów naprawy DNA, które zapewnią im przetrwanie $\mathrm{w}$ warunkach zwiększonej produkcji reaktywnych form tlenu i umożliwią inwazję odległych tkanek. Rola systemów naprawy DNA w progresji nowotworów pozostaje kwestią sporną i wydaje się być uzależniona od rodzaju nowotworu [33]. W nowotworze piersi, zarówno w komórkach pierwotnych jak i liniach pozyskanych z przerzutów, wyraźna jest tendencja do wzrostu poziomu ekspresji genów związanych $\mathrm{z}$ wieloma systemami naprawy DNA wraz ze wzrostem stopnia agresywności i tempem proliferacji komórek [11]. Transkrypcyjna kontrola i zmiany epigenetyczne zachodzące $\mathrm{w}$ obrębie regionów regulatorowych genów związanych z usuwaniem uszkodzeń DNA były do niedawna stosunkowo słabo opisane $\mathrm{w}$ literaturze. $\mathrm{W}$ najnowszych doniesieniach wykazano, że niekontrolowany wzrost oraz podziały mitotyczne są czynnikami determinującymi programy transkrypcyjne $\mathrm{w}$ nowotworach [34]. Dalsze badania przeprowadzone na komórkach nowotworu piersi powiązały transkrypcję przynajmniej części genów odpowiedzialnych za naprawę uszkodzeń DNA, których promotory charakteryzowały się obecnością wysp CpG i motywów dla czynników E2F, z tempem proliferacji komórek oraz z aktywnością BRG1. Wśród genów regulowanych przez opisane wcześniej funkcjonalne kompleksy składające się z EP300, HDAC1 i BRG1 wymienić można m.in. BRCA1, BRCA2, XRCC1, XRCC2, LIG1, EXO1, NEIL3, których produkty są ważnymi elementami szlaków naprawy przez wycinanie zasady (BER, ang. Base Excision Repair), naprawy poprzez wycinanie nukleotydu (NER, ang. Nucletide Excision Repair), naprawy pęknięć jednoniciowych (ssBR, ang. Single-Strand Break Repair) i rekombinacji homologicznej (HR, ang. Homologous Recombination [11,35]. I podobnie jak $w$ przypadku genów odpowiedzialnych za proliferację, nasilenie ekspresji genów związanych z usuwaniem uszkodzeń DNA jest wypadkową działania BRG1 jako inhibitora zatrzymania cyklu komórkowego oraz jego zdolności do usuwania acetylowanych przez EP300 histonów [10-12]. Na długiej liście genów ulegających nadekspresji w nowotworach piersi i związanych $\mathrm{z}$ ochroną materiału gene- tycznego, których promotory wykazywały wysoki stopień acetylacji i obecność BRG1, znaleźć można również enzymy modyfikujące chromatynę i DNA, których aktywność ma na celu ułatwienie maszynerii naprawczej dostępu do uszkodzonych fragmentów genomu.

Zjawisko oporności wielolekowej (MDR, ang. Multidrug Resistance) stanowi problem $\mathrm{w}$ leczeniu pacjentów zakwalifikowanych do chemioterapii i zmusza lekarzy do podnoszenia dawek stosowanych cytostatyków. Zwiększa to ryzyko uszkodzenia zdrowych tkanek i narządów oraz wystąpienia skutków ubocznych. Oporność wielolekowa dotyczy około $45 \%$ nowotworów pierwotnych i rośnie wraz z liczbą przeprowadzonych cykli chemioterapii [36]. Za oporność wielolekową odpowiedzialne są transportery ABC (ang. ATP-Binding Cassette), które w komórkach prawidłowych pełnią funkcję fizjologiczną transportując przez błony substancje odżywcze, produkty metabolizmu i leki [37]. Rodzina transporterów ABC obejmuje aż 48 białek [38]. Komórki nowotworowe m.in. jelita grubego, trzustki, jajni$\mathrm{ka}$, piersi, glejaki czy białaczki wykorzystują niektóre z nich m.in. ABCB1 (glikoproteina P), ABCC1 (MRP1; ang. Multidrug Resistance-associated Protein 1) i ABCG2 (BCRP; ang. Breast Cancer Resistance Protein) do usuwania wielu grup cytostatyków [39]. Wśród leków przeciwnowotworowych będących substratami białek ABC wymienia się cisplatynę, 5-fluorouracyl i większość antracyklin, w tym najczęściej stosowaną doksorubicynę $[37,39]$. Według danych literaturowych wysoka ekspresja receptorów z rodziny $\mathrm{ABC}$ koreluje dodatnio ze stopniem złośliwości i oporności na chemioterapeutyki a tym samym ze znacznie gorszą prognozą w grupie pacjentów ze zdiagnozowaną ostrą białaczką limfoblastyczną, nowotworem prostaty, nerek, czy płuc [40]. Stosunkowo nowe badania wykazały, że w mechanizm powstawania oporności wielolekowej może być zaangażowane białko BRG1. W komórkach nowotworu piersi BRG1 występuje $\mathrm{w}$ pobliżu miejsca inicjacji transkrypcji genów kodujących transportery takie jak: $\mathrm{ABCB} 1, \mathrm{ABCC} 1, \mathrm{ABCC} 2$, $\mathrm{ABCC} 3, \mathrm{ABCC} 4, \mathrm{ABCC} 5, \mathrm{ABCC} 11, \mathrm{ABCG} 1$, determinuje poziom transkrypcji genów, a wyciszenie ATPazy powoduje akumulację leków wewnątrz komórek. Sugeruje to, że przynajmniej część BRG1-zależnych genów kodujących transportery $\mathrm{ABC}$ odpowiada za ochronę komórek nowotworowych przed działaniem leków.

Omawiając rolę BRG1 w determinowaniu (pato)fizjologii komórek nowotworowych należy wspomnieć o udziale tego enzymu w regulowaniu transkrypcji genów aktywowanych przez jądrowe receptory hormonozależne. Pierwsze doniesienia dotyczące tego zagadnienia pochodzą z połowy lat dziewięćdziesiątych ubiegłego wieku, kiedy to wykazano, że ludzkie homologi drożdżowych białek SWI2 i Brahma - BRG1 i BRM, stymulowały ekspresję genów podczas koekspresji z receptorem estrogenowym czy retinoidowym $\mathrm{w}$ komórkach linii HepG2 [41]. Późniejsze doniesienia wykazały, że w estrogenozależnych komórkach raka piersi geny kodujące katepsynę D czy TFF1 (pS2) ulegały aktywacji w następstwie związania receptora estrogenowego wyłącznie $\mathrm{w}$ obecności BRG1. ATP-aza wiązała się z promotorami genów posiadających $\mathrm{w}$ sekwencjach promotorowych motyw wrażliwy na estrogeny (ERE; ang. Estrogen Responsive Element) za pośrednictwem receptora estrogenowego, gdzie 
usuwała nukleosomy umożliwiając transkrypcję. Za wysoki stopień acetylacji sekwencji promotorowych badanych genów odpowiadały acetylotransferazy SRC1 oraz CBP, które podobnie jak BRG1 trafiały $\mathrm{w}$ miejsce docelowe $\mathrm{w}$ formie związanej z receptorem estrogenowym tworząc wielopodjednostkową funkcjonalną jednostkę regulatorową. Należy zwrócić uwagę na rolę BRG1-SRC1/CBP-ER-zależnych genów w progresji opisywanego typu nowotworu [42]. Wspomniana wcześniej katepsyna D jest proteazą lizosomalną, której zadaniem jest aktywowanie prekursorów białek przez odcinanie ich fragmentów. Jej pro-nowotworowa rola polega na stymulowaniu proliferacji oraz angiogenezy. Warto nadmienić, że jej nadekspresję zaobserwowano w wielu przypadkach raka piersi i była ona związana z gorszym rokowaniem - skłonnością do przerzutowania oraz krótszym przeżyciem pacjenta [43]. Drugie z wymienionych białek - TFF1 ulega ekspresji we wszystkich tkankach zdolnych do wydzielania śluzu obecnych m.in. w układzie pokarmowym. W jelicie stymuluje naprawę uszkodzeń błony śluzowej i angiogenezę, a zwiększony poziom tego czynnika we krwi pacjentów cierpiących na raka piersi koreluje ze skłonnością do przerzutowania [44].

Kompleksy SWI/SNF umożliwiają również działanie receptora androgenowego (AR, z ang. Androgen Receptor). Wykazano, że kompleks ten jest niezbędny do aktywowania transkrypcji genu PSA (ang. Prostate-Specific Antigen). Badania pokazują, że większy wpływ na działanie receptora androgenowego wykazuje BRM niż BRG1, podczas gdy transkrypcja genów kontrolowanych przez receptor estrogenowy jest $\mathrm{z}$ podobną wydajnością aktywowana przez obydwie ATPazy [45].

W wielu nowotworach dochodzi do zwiększonej syntezy de novo kwasów tłuszczowych, a aktywność i ekspresja lipogennych enzymów charakteryzuje bardziej zaawansowane i złośliwe guzy. Zakłada się, że stymulacja syntezy lipidów ma pomóc nowotworom przetrwać i zachować zdolność do proliferacji w często słabo unaczynionych guzach, w których ekspansywnej komórce nowotworowej brakuje składników odżywczych. Głównym regulatorem ekspresji większości enzymów związanych z lipogenezą jest czynnik transkrypcyjny SREBP (ang. Sterol Regulatory Element Binding Protein) [46]. W prawidłowych hepatocytach BRG1 odgrywa rolę epigenetycznego kofaktora czynnika SREBP1c i umożliwia transkrypcję genów, których produkty są zaangażowane w estryfikację kwasów tłuszczowych. ATPaza wchodzi w fizyczną interakcję z czynnikiem transkrypcyjnym, który transportuje ją do docelowych sekwencji promotorowych, gdzie enzym ten zmienia konformację chromatyny ułatwiając interakcję SREBP $\mathrm{z}$ właściwym motywem w genomie [47]. Przypomina to mechanizm opisany wyżej dla receptora estrogenowego. BRG1 reguluje ekspresję genów kodujących karboksylazę acetylo-CoA (ACC), syntazę kwasów tłuszczowych (FASN), liazę ATP-cytrynianową (ACLY), ligazę długołańcuchowych kwasów tłuszczowych-CoA 1 (ACSL1) i lipinę 1 (LPIN1). Kluczowymi dla utrzymania prawidłowej gospodarki lipidowej w nowotworach są głównie ACC i FASN. ACC odpowiada za syntezę malonylo-CoA z acetylo-CoA, natomiast FASN katalizuje syntezę kwasu palmitynowego z uzyskanego malonylo-CoA. Badania przeprowadzone na komórkach raka piersi po- twierdziły udział BRG1 w regulowaniu ekspresji wymienionych wyżej genów, a obecność BRG1 zaobserwowano w ich sekwencjach promotorowych [48]. Ponadto, to poziom kwasu palimitynowego okazał się kluczowy dla proliferacji komórek nowotworowych. Dane te jednoznacznie potwierdzają zaangażowanie BRG1 w regulowanie metabolizmu komórek raka piersi poprzez wpływ na lipogenezę.

\section{BRG1 JAKO POTENCJALNY CEL TERAPII PRZECIWNOWOTWOROWYCH - PERSPEKTYWY I OGRANICZENIA}

Jak opisano wyżej, kompleksy SWI/SNF działające w oparciu o aktywność BRG1 warunkują pewne cechy komórek nowotworowych, które są istotne dla ich szybkiego wzrostu i zapewniają oporność na działanie przynajmniej części leków stosowanych obecnie w terapiach przeciwnowotworowych. Niedawno opublikowane prace wykazały, że komórki dwóch linii nowotworu piersi pozbawione aktywności BRG1 traciły zdolność do podziałów i wzrostu, ponieważ w proliferujących komórkach enzym ten aktywował transkrypcje genów kodujących czynniki odpowiedzialne na podziały mitotyczne. Biorac pod uwage specyfikę promotorów tych genów, która w znacznym stopniu uzależnia ekspresję od statusu proliferacji, a w mniejszym od specyfiki tkankowej, prawdopodobne wydaje się, że BRG1 może przyczyniać się do wzrostu także innych typów nowotworów. Enzym ten może zatem posłużyć jako cel interwencji terapeutycznej pod warunkiem, że ulega on ekspresji i występuje w formie niezmienionej przez ewentualne mutacje, które mogłyby wpływać na jego aktywność lub oddziaływanie z chromatyną. Swoiste inhibitory BRG1 mogą w przyszłości posłużyć jako narzędzia do hamowania wzrostu guzów nowotworowych, co wydaje się szczególnie istotne $\mathrm{w}$ perspektywie ograniczania rozwoju nowotworów hormononiezależnych, gdzie zasób możliwych do zastosowania związków o niskiej toksyczności w stosunku do komórek prawidłowych jest dość mocno ograniczony. Umożliwianie ekspresji genów znajdujących się pod kontrolą receptora estrogenowego przez BRG1 sugeruje, że ograniczenie jego aktywności może stanowić alternatywę dla selektywnych modulatorów receptora estrogenowego (SERMs), które obecnie są stosowane w leczeniu nowotworów hormonozależnych. Stanowią one aż 74\% wszystkich zdiagnozowanych przypadków rocznie. Wydaje się to ważne w kontekście nabywania przez komórki oporności na SERMs, co dotyczy aż jednej trzeciej przypadków nowotworów estrogenozależnych [49]. Ponadto, zahamowanie aktywności BRG1 może zwiększać wrażliwość komórek proliferujących na działanie pewnych grup leków przeciwnowotworowych, ponieważ wywołuje ono represję genów kodujących transportery błonowe usuwające substancje toksyczne oraz geny kodujące czynniki biorące udział $\mathrm{w}$ naprawie DNA. Stąd wyłania się możliwość wykorzystania inhibitorów BRG1 w terapiach skojarzonych, a najbardziej obiecującą w tym kontekście grupą chemioterapeutyków wydają się być antracykliny. Terapie skojarzone oparte na antracyklinach mogą wykorzystywać obydwie wymienione „słabości” komórek pozbawionych aktywności BRG1, ponieważ są jednocześnie substratami białek ABC oraz powodują uszkodzenia DNA. Leki te są obecnie szeroko stosowane w terapiach nowotworów piersi (32\%), chłoniaków 
(57-70\%) oraz nowotworów u dzieci (50-60\%). W grupie leków przeciwnowotworowych doksorubicyna uplasowała się na miejscu piątym zarówno pod względem częstości stosowania jak również kosztów leczenia ponoszonych przez Narodowy Fundusz Zdrowia. Pomimo faktu, że antracykliny są udokumentowanymi substratami białek ABC i są aktywnie usuwane z komórek nowotworowych, w dalszym ciągu ich zastosowanie w chemioterapii nie maleje. Wyciszenie BRG1 wywołuje również wzrost cytotoksyczności antymetabolitów (gemcytabiny, 5-fluorouracylu), inhibitorów mitozy (paklitakselu) i leków alkilujących (cisplatyny i cyklofosfamidu).

Pomimo wymienionych przesłanek w podjęciu prób klinicznego zastosowania ograniczenia aktywności BRG1 czynnikiem limitującym jest obecność tylko jednego, komercyjnie dostępnego inhibitora tego enzymu - PFI3. Według bazy ClinicalTrials.gov nie jest on przedmiotem żadnego prowadzonego obecnie badania, brakuje zatem informacji o zarówno pozytywnych jak i ubocznych efektach jego działania. Sytuację dodatkowo komplikuje fakt, że hamuje on aktywność obydwu ATPaz występujących w kompleksach SWI/SNF - BRG1 i BRM, co wynika z wysokiej homologii obydwu enzymów. Biorąc pod uwagę złożone wzajemne relacje funkcjonalne pomiędzy dwiema ATPazami, których podłoże dotychczas nie zostało poznane, trudno przewidzieć jaki wpływ na żywotność i proliferację różnych typów nowotworów będzie mieć jednoczesna inhibicja BRG1 i BRM. Nawet swoiste hamowanie aktywności BRG1 może potencjalnie przynieść odwrotne do zamierzonych efekty, ponieważ enzym ten pełni w komórkach zarówno funkcję aktywatora transkrypcji jak i represora. Trudno zatem przewidzieć skutki przywrócenia ekspresji pewnej puli genów, która wyciszona jest przez BRG1. Należy zwrócić także uwagę na fakt, że kompleksy SWI/SNF kontrolują transkrypcję w komórkach prawidłowych, stąd ich inhibicja może nie pozostać bez wpływu na funkcjonowanie tkanek czy nawet całych narządów.

Pewnym ułatwieniem w próbach swoistej inhibicji BRG1 może okazać się fakt współpracy BRG1 z innymi enzymami remodelującymi chromatynę. Enzym ten pełni funkcję "dekodera" informacji zapisanej w kodzie epigenetycznym, więc o usunięciu nukleosomów z danej sekwencji promotorowej, a tym samym aktywowaniu lub hamowaniu ekspresji genu zależnego od aktywności BRG1, decydują inne enzymy modyfikujące histony takie jak acetylotransferazy i deacetylazy, metylotransferazy czy demetylazy oraz wiele innych. Sugeruje to, że inhibitory enzymów modyfikujących histony, charakteryzujące się zwykle stosunkowo dużą swoistością, mogą pośrednio hamować aktywność BRG1 i pełnić w pewnych przypadkach rolę swoistych inhibitorów transkrypcji genów BRG1-zależnych. W omawianym kontekście zastosowanie mogą znaleźć także inhibitory bromodomen $[6,50]$. Motywy te obecne są w obydwu ATP-azach SWI/SNF, ale także w wielu enzymach występujących na chromatynie, również w tych, które współpracują z BRG1. Chociaż jednoczesne zahamowanie aktywności dwóch białek odpowiedzialnych za ekspresję genu wywoła prawdopodobnie silniejszy efekt, to stosunkowo liczna grupa enzymów posiadających w swojej strukturze bromodomenę zmniejszyć może swoistość działania inhibitora.
Co istotne szczególnie w kontekście klinicznym, aktywność transkrypcyjna kompleksów EP300-BRG1 jest regulowana przez PARP1. Dotyczy to przynajmniej części genów E2F-zależnych, zawiązanych z proliferacją i naprawą DNA. Inhibitor PARP1 - olaparib w badanych liniach nowotworu piersi okazał się represorem obydwu grup genów. Można zatem przypuszczać, że zakres stosowania inhibitorów tego enzymu, które zostały dopuszczone przez amerykańską Administrację Żywności i Leków (FDA; ang. Food and Drug Administration) do leczenia wybranych typów nowotworów, ulegnie rozszerzeniu gdyż nadrzędną rolę w regulowaniu ekspresji przynajmniej części genów związanych z proliferacją i naprawą DNA odgrywa status proliferacji komórek. Jest zatem prawdopodobne, że PARP1, którego poziom jest wysoki w większości komórek nowotworowych, okaże się aktywatorem ekspresji genów kontrolowanych przez kompleksy EP300-BRG1 występujące na promotorach CpG/ E2F-dodatnich w szerokim spektrum nowotworów. Oprócz opisanych wyżej i funkcjonalnie powiązanych genów, na długiej liście promotorów cechujących się obecnością kompleksów PARP1-EP300- BRG1 w liniach nowotworu piersi, znajdują się również te, które regulują metabolizm, sygnalizację wewnątrzkomórkową, organizację wewnątrzkomórkowych organelli, organizację DNA czy potranslacyjne modyfikacje histonów. Inhibitory PARP1 mogą znaleźć zastosowanie w wyciszaniu wielu wewnątrzkomórkowych procesów zależnych od interakcji EP300 z BRG1, które są podstawą patofizjologii nowotworów lub odpowiadają za brak wrażliwości tych komórek na działanie leków.

\section{PODSUMOWANIE}

Odkrycie molekularnego mechanizmu leżącego u podstaw udziału kompleksów SWI/SNF opartych na aktywności BRG1 w determinowaniu patofizjologii nowotworów umożliwia podjęcie prób wykorzystania w przyszłości inhibitorów BRG1 i/lub współpracujących z nim enzymów w monoterapiach lub terapiach skojarzonych do hamowania wzrostu guzów i zwiększania ich wrażliwości na działanie niektórych leków. Niskie prawdopodobieństwo uzyskania swoistego inhibitora BRG1, wynikające z jego dużego podobieństwa do BRM, pociąga za sobą uzasadnioną konieczność prowadzenia dalszych badań nad funkcjonalnymi zależnościami pomiędzy BRG1 i enzymami zaangażowanymi w definiowanie kodu epigenetycznego w celu wyłonienia związków posiadających potencjał do intencjonalnego regulowania ekspresji wybranej puli genów BRG1-zależnych.

\section{PIŚMIENNICTWO:}

1. Clapier CR, Iwasa J, Cairns BR, Peterson CL (2017) Mechanisms of action and regulation of ATP-dependent chromatin-remodelling complexes. Nat Rev Mol Cell Biol 18: 407-422

2. Trotter KW, Archer TK (2008) The BRG1 transcriptional coregulator. Nucl Recept Signal 6: e004

3. Trotter KW, Fan H-Y, Ivey ML, Kingston RE, Archer TK (2008) The HSA domain of BRG1 mediates critical interactions required for glucocorticoid receptor-dependent transcriptional activation in vivo. Mol Cell Biol 28: 1413-1426

4. Vignali M, Hassan AH, Neely KE, Workman JL (2000) ATP-Dependent chromatin-remodeling complexes. Mol Cell Biol 20: 1899-1910 
5. Tails AH, Shen W, Xu C, Huang W, Zhang J, Carlson JE, et al. (2007) Solution structure of human Brg1 bromodomain and its specific binding to. Biochemistry 46: 2100-2110

6. Morrison EA, Sanchez JC, Ronan JL, Farrell DP, Varzavand K, Johnson JK, et al. (2017) DNA binding drives the association of BRG1/hBRM bromodomains with nucleosomes. Nat Commun 8: 1-14

7. Mehta G, Kumarasamy S, Wu J, Walsh A, Liu L, Williams K, et al. (2017) MITF interacts with the SWI/SNF subunit, BRG1, to promote GATA4 expression in cardiac hypertrophy. Physiol Behav 176: 139148

8. Shanahan F, Seghezzi W, Parry D, Mahony D, Lees E (1999) Cyclin E Associates with BAF155 and BRG1, components of the mammalian SWI-SNF complex, and alters the ability of BRG1 to induce growth arrest. Mol Cell Biol 19: 1460-1469

9. Consortium TU (2018) UniProt: a worldwide hub of protein knowledge. Nucleic Acids Res 47: D506-D515

10. Pietrzak J, Płoszaj T, Pułaski Ł, Robaszkiewicz A (2019) EP300-HDAC1-SWI/SNF functional unit defines transcription of some DNA repair enzymes during differentiation of human macrophages. Biochim Biophys Acta - Gene Regul Mech 1862: 198-208

11. Sobczak M, Pietrzak J, Płoszaj T, Robaszkiewicz A (2020) BRG1 Activates proliferation and transcription of cell cycle-dependent genes in breast cancer cells. Cancers 12: 1-18

12. Sobczak M, Pitt AR, Spickett CM, Robaszkiewicz A (2019) PARP1 Co-regulates EP300-BRG1-dependent transcription of genes involved in breast cancer cell proliferation and DNA repair. Cancers 11: 1-18

13. Brockmann D, Lehmkühler O, Schmücker U, Esche H (2001) The histone acetyltransferase activity of PCAF cooperates with the brahma/ SWI2-related protein BRG-1 in the activation of the enhancer A of the MHC class I promoter. Gene 277: 111-120

14. Weng X, Yu L, Liang P, Li L, Dai X, Zhou B, et al. (2015) A crosstalk between chromatin remodeling and histone H3K4 methyltransferase complexes in endothelial cells regulates angiotensin II-induced cardiac hypertrophy. J Mol Cell Cardiol 82: 48-58

15. Schwabish MA, Struhl K (2007) The Swi/Snf Complex is important for histone eviction during transcriptional activation and RNA polymerase II elongation in vivo. Mol Cell Biol 27: 6987-6995

16. Wiśnik E, Płoszaj T, Robaszkiewicz A (2017) Downregulation of PARP1 transcription by promoter-associated E2F4-RBL2-HDAC1-BRM complex contributes to repression of pluripotency stem cell factors in human monocytes. Sci Rep 7: 1-14

17. Wu Q, Lian JB, Stein JL, Stein GS, Nickerson JA, Imbalzano AN (2017) The BRG1 ATPase of human SWI/SNF chromatin remodeling enzymes as a driver of cancer. Epigenomics 9: 919-931

18. Romero OA, Sanchez-Cespedes M (2014) The SWI/SNF genetic blockade: Effects in cell differentiation, cancer and developmental diseases. Oncogene 33: 2681-2689

19. Reisman DN, Sciarrotta J, Wang W, Funkhouser WK, Weissman BE (2003) Loss of BRG1/BRM in human lung cancer cell lines and primary lung cancers: Correlation with poor prognosis. Cancer Res 63: 560-566

20. Marquez SB, Thompson KW, Lu L, Reisman D (2014) Beyond mutations: Additional mechanisms and implications of SWI/SNF complex inactivation. Front Oncol 4: 1-20

21. Guerrero-Martínez JA, Reyes JC (2018) High expression of SMARCA4 or SMARCA2 is frequently associated with an opposite prognosis in cancer. Sci Rep 8: 1-17

22. Do SI, Yoon G, Kim HS, Kim K, Lee H, Do IG, et al. (2016) Increased brahma-related gene 1 expression predicts distant metastasis and shorter survival in patients with invasive ductal carcinoma of the breast. Anticancer Res 36: 4873-4882

23. Orlando KA, Nguyen V, Raab JR, Walhart T, Weissman BE (2019) Remodeling the cancer epigenome: mutations in the SWI/SNF complex offer new therapeutic opportunities. Expert Rev Anticancer Ther 19: 375-391

24. Caumanns JJ, Wisman GBA, Berns K, van der Zee AGJ, de Jong $S$ (2018) ARID1A mutant ovarian clear cell carcinoma: A clear target for synthetic lethal strategies. Biochim Biophys Acta - Rev Cancer 1870: 176-184

25. Takao C, Morikawa A, Ohkubo H, Kito Y, Saigo C, Sakuratani T, et al. (2016) Downregulation of ARID1A, a component of the SWI/SNF chromatin remodeling complex, in breast cancer. J Cancer 8: 1-8

26. Wang HK, Qu YY, Dai B, Zhu Y, Shi GH, Zhu YP, et al. (2017) PBRM1 regulates proliferation and the cell cycle in renal cell carcinoma through a chemokine/chemokine receptor interaction pathway. PLoS One 12: $1-13$

27. Mota STS, Vecchi L, Zóia MAP, Oliveira FM, Alves DA, Dornelas BC, et al. (2019) New insights into the role of polybromo-1 in prostate cancer. Int J Mol Sci 20: 1-16

28. Hodis E, Watson IR, Kryukov G V., Arold ST, Imielinski M, Theurillat J-P, et al. (2012) A Landscape of Driver Mutations in Melanoma. Cell 150: 251-263

29. Zhao H, Wang J, Han Y, Huang Z, Ying J, Bi X, et al. (2011) ARID2: A new tumor suppressor gene in hepatocellular carcinoma. Oncotarget 2: 886-891

30. Raab JR, Runge JS, Spear CC, Magnuson T (2017) Co-regulation of transcription by BRG1 and BRM, two mutually exclusive SWI/SNF ATPase subunits. Epigenetics and Chromatin 10: 1-15

31. Trizzino M, Barbieri E, Petracovici A, Wu S, Welsh SA, Owens TA, et al. (2018) The tumor suppressor ARID1A controls global transcription via pausing of RNA polymerase II. Cell Rep 23: 3933-3945

32. Dunaief JL, Strober BE, Guha S, Khavari PA, Alin K, Luban J, et al. (1994) The retinoblastoma protein and BRG1 form a complex and cooperate to induce cell cycle arrest. Cell 79: 119-130

33. Broustas CG, Lieberman HB (2014) DNA Damage response genes and the development of cancer metastasis. Radiat Res 181: 111-130

34. Selfors LM, Stover DG, Harris IS, Brugge JS, Coloff JL (2017) Identification of cancer genes that are independent of dominant proliferation and lineage programs. Proc Natl Acad Sci U S A 114: E11276-E11284

35. Christmann M, Kaina B (2013) Transcriptional regulation of human DNA repair genes following genotoxic stress: Trigger mechanisms, inducible responses and genotoxic adaptation. Nucleic Acids Res 41: 8403-8420

36. Chelamalla R (2017) Drug resistance: important criteria for cancer drug development. Pharm Biol Eval 4: 127-129

37. Ween MP, Armstrong MA, Oehler MK, Ricciardelli C (2015) The role of $\mathrm{ABC}$ transporters in ovarian cancer progression and chemoresistance. Crit Rev Oncol Hematol 96: 220-256

38. Wilkens S (2015) Structure and mechanism of ABC transporters. F1000Prime Rep 7: 14

39. Begicevic RR, Falasca M (2017) ABC transporters in cancer stem cells: Beyond chemoresistance. Int J Mol Sci 18: 2362

40. Pasello M, Giudice AM, Scotlandi K (2019) The ABC subfamily A transporters: Multifaceted players with incipient potentialities in cancer. Seminars in Cancer Biology 60: 57-71

41. Chiba H, Muramatsu M, Nomoto A, Kato H (1994) Two human homologues of saccharomyces cerevisiae SWI2/SNF2 and Drosophila brahma are transcriptional coactivators cooperating with the estrogen receptor and the retinoic acid receptor. Nucleic Acids Res 22: 1815-1820

42. DiRenzo J, Shang Y, Phelan M, Sif S, Myers M, Kingston R, et al. (2000) BRG-1 Is recruited to estrogen-responsive promoters and cooperates with factors involved in histone acetylation. Mol Cell Biol 20: 75417549

43. Liaudet-Coopman E, Beaujouin M, Derocq D, Garcia M, Glondu-Lassis M, Laurent-Matha V, et al. (2006) Cathepsin D: newly discovered functions of a long-standing aspartic protease in cancer and apoptosis. Cancer Lett 237: 167-179

44. Elnagdy MH, Farouk O, Seleem AK, Nada HA (2018) TFF1 and TFF3 mRNAs are higher in blood from breast cancer patients with metastatic disease than those without. J Oncol 2018: 4793498

45. Marshall TW, Link KA, Petre-Draviam CE, Knudsen KE (2003) Differential requirement of SWI/SNF for androgen receptor activity. Journal of Biological Chemistry 278: 30605-30613 
46. Nickerson JA, Wu Q, Imbalzano AN (2017) Mammalian SWI/SNF enzymes and the epigenetics of tumor cell metabolic reprogramming. Front Oncol 7: 1-9

47. Li N, Li M, Hong W, Shao J, Xu H, Shimano H, et al. (2018) Brg1 regulates pro-lipogenic transcription by modulating SREBP activity in hepatocytes. Biochim Biophys Acta - Mol Basis Dis 1864: 2881-2889

48. Wu Q, Madany P, Dobson JR, Schnabl JM, Sharma S, Smith TC, et al. (2016) The BRG1 chromatin remodeling enzyme links cancer cell metabolism and proliferation. Oncotarget 7: 38270-38281
49. Carroll JS (2016) Eje prize 2016: Mechanisms of oestrogen receptor (ER) gene regulation in breast cancer. Eur J Endocrinol 175: R41-R49

50. Sanchez R, Meslamani J, Zhou M-M (2014) The bromodomain: From epigenome reader to druggable target. Biochim Biophys Acta - Gene Regul Mech 1839: 676-685

\title{
Contribution of BRG1-dependent SWI/SNF complexes to determining the phenotype of cancer cell
}

\author{
Maciej Sobczak, Magdalena Strachowska, Agnieszka Robaszkiewicz ${ }^{\bigotimes}$
}

Department of General Biophysics, Faculty of Biology and Environmental Protection, University of Lodz, Pomorska 141/143, 90-236 Łódź

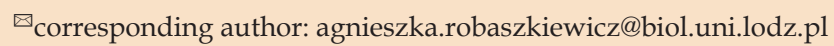

Key words: Brahma-related gene 1 (BRG1), regulation of gene transcription, epigenetics, cancer

\section{SUMMARY}

ATP-dependent chromatin remodeling complexes are documented as indispensible element of epigenetic mechanisms, which control transcription. These multiprotein functional units are capable of insertion, deletion and sliding of nucleosomes at the gene regulatory elements thereby defining DNA accessibility to transcription machinery. SWI/SNF is one out of four identified and described complexes. The enzymatic role in SWI/SNF molecular "motors" is assigned to two ATP-ases: BRM and BRG1. Accumulating evidence suggests the link between BRG1 and pathophysiology of some types of cancer. BRG1 has been documented as an activator of genes encoding factors responsible for i.a. proliferation, DNA repair, transmembrane transport and metabolism. Therefore, inhibitors of BRG1 and co-operating enzymes, which modulate activity of this ATP-ase or mark histones for shuttling to/from the chromatin, may turn out as an alternative to the compounds that are currently used to suppress the growth of tumors or as supplements that increase cell vulnerability to anticancer drugs. 